J. Clin. Chem. Clin. Biochem.

Vol. 19, 1981, pp. 977-978

\title{
A New Enzymatic Method for the Determination of Glucose
}

\author{
By F. Heinz and Th. W. Beushausen') \\ Zentrum Biochemie, Medizinische Hochschule Hannover
}

(Received March 26/September 8, 1980)

Summary: A method for the determination of glucose is described. $\mathrm{H}_{2} \mathrm{O}_{2}$, produced by the action of glucose oxidase, is measured from the change in absorbance due to oxidation of $\mathrm{NAD}(\mathrm{P}) \mathrm{H}$ in the presence of catalase, aldehyde dehydrogenase and a high concentration of ethanol. The quality data of the method are equivalent to those of the hexokinase-glucose-6-phosphate dehydrogenase method used as reference.

\section{Eine neue enzymatische Methode zur Bestimmung von Glucose}

Zusammenfassung: Bei der beschriebenen Glucosebestimmung wird das durch Glucoseoxidase entstandene $\mathrm{H}_{2} \mathrm{O}_{2}$ mit Katalase und Aldehyddehydrogenase in Anwesenheit von hohen Ethanolkonzentrationen bestimmt; dabei dient NAD(P)H als Meßgröße. Die Qualitätsmerkmale der Methode entsprechen denen der Hexokinase-Glucose-6-phosphatdehydrogenase Referenzmethode.

\section{Introduction}

Glucose determination is one of the most frequently used methods in clinical chemistry, and is based mainly on three enzymatic-photometric assays: the NADP dependent hexokinase-glucose-6-phosphate dehydrogenase method (1), the NAD-dependent glucose dehydrogenase method (2) and the $\mathrm{H}_{2} \mathrm{O}_{2}$-producing glucose oxidase-peroxidase method coupled with leuco dyes (3).

Our assiay is based on the glucose oxidase reaction, with measurement of the produced $\mathrm{H}_{2} \mathrm{O}_{2}$, using catalase and NAD(P)-dependent aldehyde dehydrogenase in the presence of high ethanol concentrations. This principle (4), which has already been evaluated for uric acid (5) and cholesterol (6) avoids the known difficulties arising from the use of peroxidase coupled with leuco dyes.

\section{Reactions}

(1) $D$-glucose $+1 / 2 \mathrm{O}_{2}+\mathrm{H}_{2} \mathrm{O}$

$$
\underset{\text { oxidase }}{\stackrel{\text { glucose }}{\longrightarrow}} D \text {-gluconic acid }+\mathrm{H}_{2} \mathrm{O}_{2}
$$

(2) $\mathrm{H}_{2} \mathrm{O}_{2}+$ ethanol $\stackrel{\text { catalase }}{\longrightarrow}$ acetaldehyde $+2 \mathrm{H}_{2} \mathrm{O}$

(3) acetaldehyde $+\mathrm{NAD}(\mathrm{P})+\mathrm{H}_{2} \mathrm{O}$

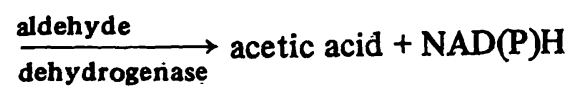

1) This work contains part of the doctor thesis of Th. W. Beushousen

\section{Materials and Methods}

KCl-diphosphate buffer ( $p H$ 8.0): Dissolve $11.15 \mathrm{~g}$ tetrasodiumdiphosphate-10-hy drate (Merck No. 6591) and $11.85 \mathrm{~g} \mathrm{KCl}$ (Merck No. 4936) in $400 \mathrm{ml} \mathrm{H}_{2} \mathrm{O}$; adjust $\mathrm{pH}$ to 8.0 with $\mathrm{HCl}$ and add $\mathrm{H}_{2} \mathrm{O}$ to $500 \mathrm{ml}$.

Aldehyde dehydrogenase solution: Dissolve a $10 \mathrm{U}$ equivalent of aldehyde dehydrogenase, $\mathrm{K}^{+}$activated from baker's yeast, grade II (No. A-6758, Fa. Sigma, St. Louis) in $1 \mathrm{ml} \mathrm{H}_{2} \mathrm{O}$.

NAD-solution: Dissolve $10 \mathrm{mg}$ NAD (No. 15298, Fa. Boehringer, Mannheim) in $1 \mathrm{ml} \mathrm{H}_{2} \mathrm{O}$.

Glucose oxidase solution: Dissolve an $1100 \mathrm{U}$ equivalent of glucose oxidase lyophilisate (No. 15426, Fa. Boehringer, Mannheim) in $0.5 \mathrm{ml} \mathrm{H}_{2} \mathrm{O}$.

Buffer/ethanol mixture: Mix $10 \mathrm{ml}$ buffer and $1 \mathrm{ml}$ ethanol. Catalase: Catalase 1.43 GU/1 (Fa. CalBiochem., Lot. 600660).

Reaction mixture (for 10 determinations): Take $8.5 \mathrm{ml}$ buffer/ ethanol mixture, add $1 \mathrm{ml}$ NAD-solution, $1 \mathrm{ml}$ aldehyde dehydrogenase solution, $0.5 \mathrm{ml}$ glucose oxidase solution, and $10 \mu \mathrm{l}$ catalase.

This mixture is incubated at room temperature for $1 \mathrm{~h}$. At $4^{\circ} \mathrm{C}$, it is stable for approximately $24 \mathrm{~h}$.

\footnotetext{
Manual procedure

Pipette $1 \mathrm{ml}$ of the reaction mixture into a semimicro cuvette with $10 \mathrm{~mm}$ optical path length, then read absorbance for 1-3 min at 334 or $340 \mathrm{~nm} \mathrm{Hg}$ and add $5 \mu \mathrm{l}$ sample. Mix, then read absorbance when the reaction has come to the end (reaction temperature: $25^{\circ} \mathrm{C}$ ). Before and after the end of the reaction a slight endogenous slope is found. By extrapolation back to the starting point the absorbance difference is determined. The glucose concentration is calculated from the absorbance difference. By using NADP instead of NAD identical results were obtained.
} 
Results

The accuracy of the method was established by determining the glucose concentration in aqueous solutions of known glucose concentrations, in control sera containing known concentrations and by determination of the glucose concentration in patients' sera with our method and the hexokinase-glucose-6-phosphate dehydrogenase method (1). The results of both methods were compared with the paired-t-test, which did not show significant differences. The regression analysis for patients' sera is shown in figure 1.

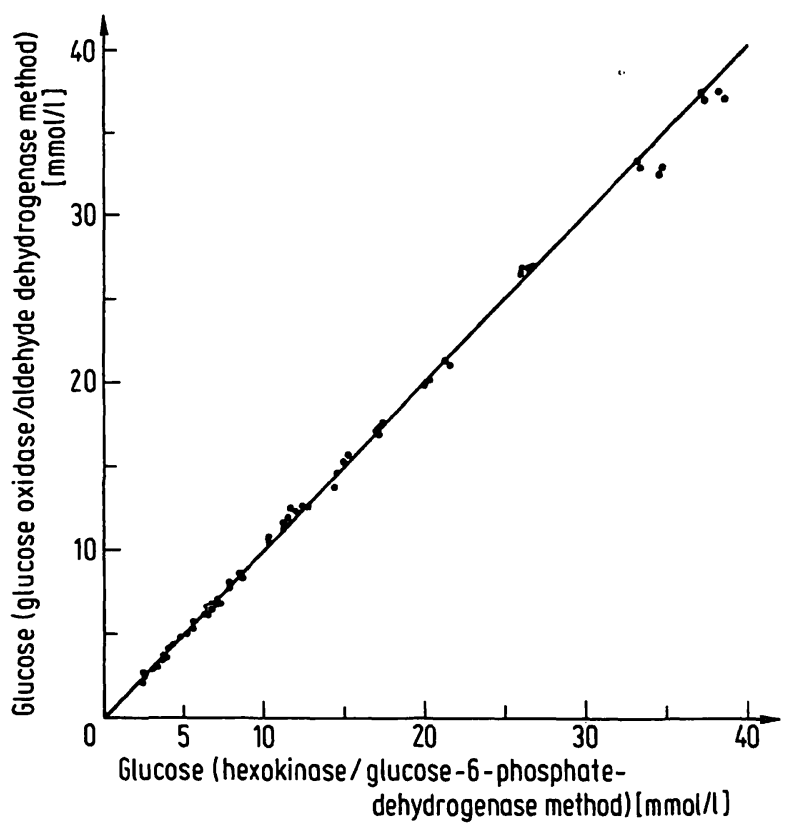

Fig. 1. Linear regression for glucose concentration in 29 patients' sera determined with the glucose oxidase-aldehyde dehydrogenase method $(y)$ and the hexokinase-glucose-6phosphate dehydrogenase method $(x)$.

$\mathrm{y}=1.00-0.03 \quad \mathrm{r}=0.999 \quad \mathrm{n}=58$

Paired t-test:

$\mathrm{f}=57 \quad \alpha=0.05 \quad \mathrm{t}_{0}=1.43$
The precision from day to day for control sera was CV $<3.08 \%(n=55)$, which almost meets the figure of the American College of Pathologists (CV <2.2\%) (7), and which is well below the requirements of the guidelines of the Medical Society of the Federal Republic of Germany $(\mathrm{CV}<5 \%)(7)$.

For normal sera or those with slight haemolysis, hyperlipidaemia or hyperbilirubinaemia, the absorbance value of the sample is negligible. For strongly haemolytic samples, turbid hyperlipidaemic samples or samples with well elevated bilirubin levels $(>115 \mu \mathrm{mol} / \mathrm{l})$, the absorbance value of the sample volume has to be determined in a reaction mixture without glucose oxidase, and then subtracted.

\section{Discussion}

The described method is suitable for the determination of glucose in human sera. The linear range of the method was verified for concentrations from $2-38 \mathrm{mmol} / \mathrm{l}$, thus permitting determination of almost any normal or pathologic glucose concentration.

Relevant inhibitor substances for glucose oxidase or aldehyde dehydrogenase are not known in human sera. For the evaluation of a uric acid determination method, which has the same indicator system, a number of substances often used clinically were tested for possible interference. No interference by these substances was noted (5).

Compared to other glucose oxidase methods coupled with leuco dyes, our method has several advantages: The reaction time is $10-15 \mathrm{~min}$ shorter. The glucose concentration can be calculated directly from the absorbance difference using the coefficient of absorbance for NAD(P)H. Stabilisation of the indicator is not necessary. The manual procedure for our method is rather simple and it can be easily automatized.

\section{References}

1. Bergmeyer, H.-U. \& Gawehn, K. (1974) in: Methoden der enzymatischen Analyse (Bergmeyer, H.-U. ed.) Verlag Chemie, Weinheim, $3^{\text {rd }}$ ed., p. 1241-1246.

2. Banauch, D., Brümmer, W., Ebeling, W., Metz, H., Rindfrey, H., Lang, H., Leybold, K. \& Rick, W. (1975) this J. 13, 101107.

3. Bergmeyer, H.-U. \& Bernt, C. (1974) Methoden der enzymatischen Analyse (Bergmeyer, H.-U. ed.) Verlag Chemie, Weinheim, $3^{\text {rd }}$ ed., p. $1250-1257$.
4. Haeckel, R. \& Heinz, F. (1975) this j. 13, 244.

5. Haeckil, R. (1976) this j. 14, 101-107.

6. Haeckel, R. \& Perlick, M. (1976) this j. 14, 411-414.

7. Haeckel, R. (1975) Qualitätssicherung im klinischen Labor, Dtsch. Ârzteverlag Köln, p. 43.

Prof. Dr. Fritz Heinz

Zentrum Biochemie - 4310 -

Medizinische Hochschule Hannover

Karl-Wiechert-Allee 9

D-3000 Hannover 61 
J. Clin. Chem. Clin. Biochem.

Vol. 19, 1981, pp. 979-981

\title{
Urinary Excretion of Cyclic Guanosine $3^{\prime} .5^{\prime}$-monophosphate in Children with Malignant Tumours ${ }^{1}$ )
}

\author{
By B. Puschendorf, H. Grunicke
}

Institut für Medizinische Chemie und Biochemie (Vorstand: Prof. Dr. H. Grunicke) der Universität Innsbruck

\author{
J. Jentsch and $H$. Berger
}

Kinderklinik(Vorstand: Prof. Dr. H. Berger) der Universität Innsbruck

(Received November 27, 1980/March 13, 1981)

Dedicated to Professor Dr. Helmut Holzer on his 60 th birthday

Summary: The present study shows an increased urinary cyclic guanosine $3^{\prime} .5^{\prime}$-monophosphate (cyclic GMP) excretion rate in children of all age groups bearing malignant tumours or lymphomas. The incidence of increased cyclic GMP excretion was highly significant (79\%). Follow-up studies of up to three years have revealed that during periods of remission of malignant disease the urinary cyclic GMP excretion drops to near normal values, whereas recurrences are accompanied by a new increase of cyclic GMP excretion.

\section{Ausscheidung von zyklischem Guanosin-3'.5'-monophosphat im Urin von Kindern mit malignen Tumoren}

Zusammenfassung: Die vorliegende Studie zeigt eine erhöhte Ausscheidung von zyklischem Guanosin- $3^{\prime} .5^{\prime}$-monophosphat (zyklisches GMP) im Urin von Kindern aller Altersgruppen mit malignen Tumoren oder Lymphomen. Das Auftreten dieser zyklischen GMP-Ausscheidung im Urin war mit 79\% hoch signifikant. Verlaufsstudien bis zu 3 Jahren zeigten während der Remission der malignen Erkrankung eine Ausscheidung, die bis zu Normalwerten abfiel, hingegen waren Rezidive von einer erneuten Erhöhung der Ausscheidung von zyklischem GMP begleitet.

\section{Introduction}

Earlier observations $(1,2)$ have suggested that an elevation of guanosine $3^{\prime} .5^{\prime}$-monophosphate (cyclic GMP) promoted cell division. Murad et al. (3) demonstrated an increased urinary excretion of cyclic GMP in rats bearing transplantable liver and kidney tumours. The excretion of cyclic GMP in these animals decreased after radiotherapy, chemotherapy, or excision of the tumours and correlated well with the tumour size and growth. The same group (4) found that urinary cyclic GMP, but not cyclic adenosine $3^{\prime} .5^{\prime}$-monophosphate (cyclic AMP), increased progressively with the growth of several, but not all transplantable liver and kidney tumours studied. Stimulated by these findings we made an attempt to correlate the urinary cyclic GMP excretion rate ( $\mu$ mol per gram creatinine) with the clinical course of malignant tumours in children.

1) Parts of this paper were presented as a preliminary communication at the Gemeinsame Jahrestagung der Deutschen und Österreichischen Gesellschaften für Klinische Chemie, March 1979, Salzburg, Austria.

\section{Material and Methods}

Urine was collected at room temperature and was stored at $-20^{\circ} \mathrm{C}$ until assayed. The urinary cyclic GMP was measured by a radioisotope dilution test with cyclic GMP binding protein (Boehringer, Mannheim, Germany) (5-7). Urinary levels of creatinine were determinated by the picric acid method (8). The values reported for urinary cyclic GMP excretion are the mean values of duplicate determinations and are expressed as $\mu \mathrm{mol}$ per $g$ creatinine.

\section{Results and Discussion}

Several reported data demonstrate a positive correlation between the intracellular level of cyclic GMP and the cell proliferation $(1,2)$. Therefore, it seemed possible that newborn children would have an elevated excretion of cyclic GMP due to their higher rate of cell proliferation. Figure 1 shows the urinary excretion of cyclic GMP by children as a function of age. The youngest children were premature births (36 weeks of pregnancy). The excretion rates of cyclic GMP were considerably higher in young children (below 2 years) and decreased with age. This result is probably due to the normally decreased excretion of creatinine in young children $(9$, 


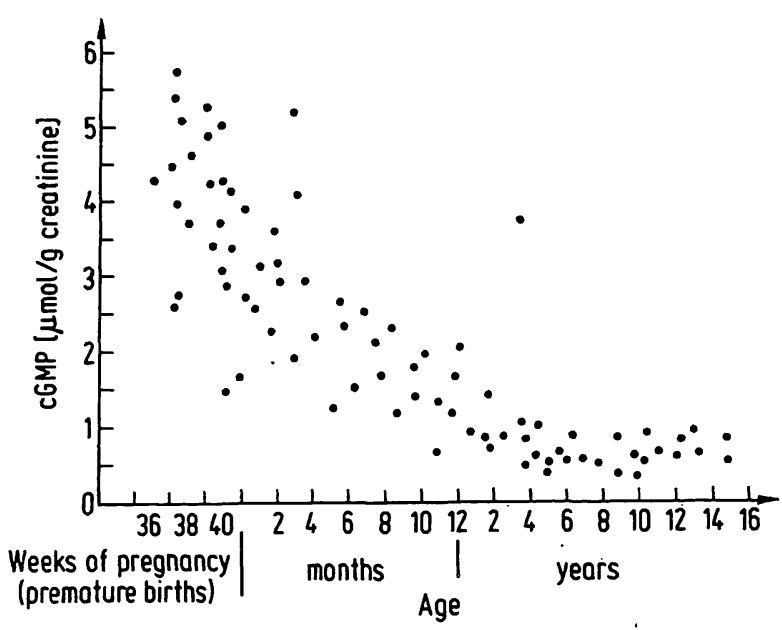

Fig. 1. Urinary cyclic GMP excretion rates in children, as a function of age.

10), rather than by an increased level of cyclic GMP. The upper limit of urinary excretion of cyclic GMP in children younger than two years, is $5 \mu \mathrm{mol} / \mathrm{g}$ creatinine; whereas the normal range in children older than 2 years

Tab. 1. Urinary cyclic GMP excretion rates in children with tumours and other diseases (Pediatric Clinic of the University of Innsbruck/Austria; observation period: 19771979).

\begin{tabular}{llllll}
\hline $\begin{array}{l}\text { Cyclic GMP } \\
\text { (umol/g }\end{array}$ & $<1.0$ & $1.0-$ & $1.51-$ & $>2.0$ & $\begin{array}{l}\text { Values } \\
>1.5 \\
(\%)\end{array}$ \\
creatinine) & & 1.50 & 2.0 & & $(\%)$ \\
\hline
\end{tabular}

\begin{tabular}{lrrrrr}
\hline $\begin{array}{l}\text { Untreated } \\
\text { tumours*) }\end{array}$ & 4 & 8 & 16 & 25 & 77 \\
$\begin{array}{l}\text { Untreated } \\
\text { leukaemias**) }\end{array}$ & 1 & 1 & 4 & 11 & 88 \\
$\begin{array}{l}\text { Recurrences of } \\
\text { leukaemias }\end{array}$ & 2 & 2 & 7 & 6 & 76 \\
$\quad$ total: & 7 & 11 & 27 & 42 & 79 \\
$\begin{array}{l}\text { Treated } \\
\text { tumours }\end{array}$ & 19 & 22 & 2 & 8 & 21 \\
$\begin{array}{l}\text { Leukaemias in } \\
\text { remission }\end{array}$ & 13 & 18 & 11 & 6 & 35 \\
$\begin{array}{l}\text { Other } \\
\text { diseases }\end{array}$ & 33 & 32 & 9 & 11 & 24 \\
\hline
\end{tabular}

*) Total 53 determinations; number of cases in brackets: brain tumours (13) (ependymoma (2), craniopharyngioma (2), pineal tumour (1), medulloblastoma (3), spongioblastoma (1), brainstem tumour (1), astrocy toma (2), unclassified (2)); lymphomas (7) (M. Hodgkin: stage I (1), stage III (1), Burkitt-lymphoma (1), non-Hodgkin-lymphoma stage IV (4)); Wilms tumours (5) (stage II (3), stage III (1), stage. IV (1)); neuroblastomas stage IV (3) sarcomas (3) (stage IV (1), sarcoma botryoides (1), angiosarcoma (1)); osteosarcomas without metastases (2).

2 determinations were performed at different time points in 5 cases (brain tumour, Wilms tumour, ncuroblastoma, sarcoma and lymphoma), and 15 values are determinations during the recurrences of the tumours (brain tumours, Wilms tumours, neuroblastoma, sarcoma and lymphomas).

**) acute lymphatic leukaemias (12), acute myeloic leukaemias (2), and acute monocy tic leukaemia (1). 2 determinations werc performed at different time points in 2 cases (acute lymphatic leukaemia).

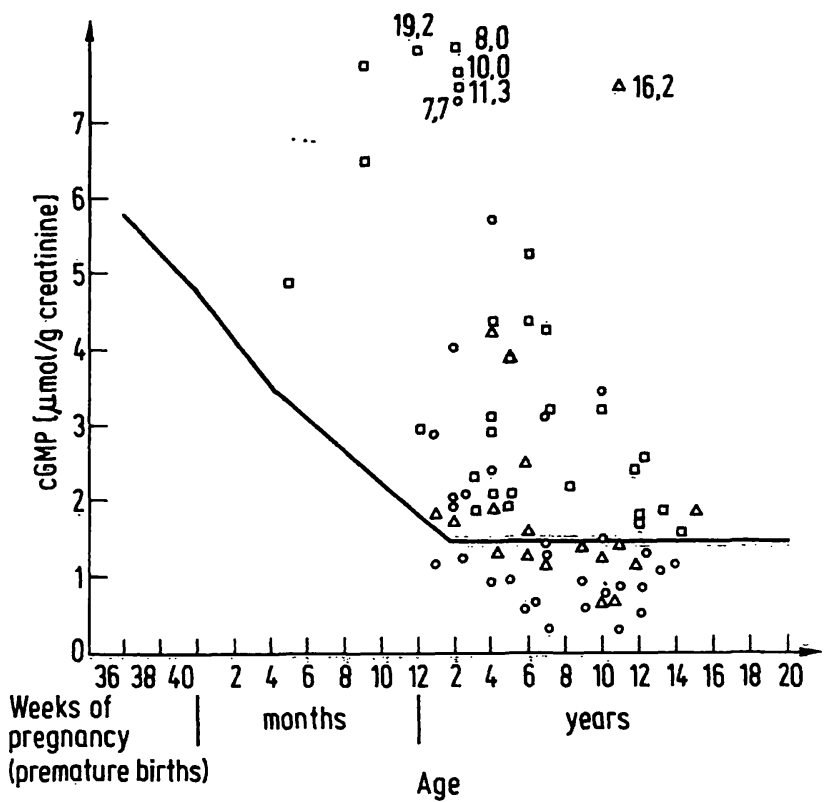

Fig. 2. Urinary cyclic GMP excretion rates in children bearing malignant tumours and lymphoproliferative diseases, as a function of age.

o untreated tumours, $\circ$ treated tumours $\Delta$ brain tumours.

is $0.5-1.2 \mu \mathrm{mol} / \mathrm{g}$ creatinine. The normal level of cyclic GMP in plasma has been determined as $1.2 \mathrm{nmol} / \mathrm{l}$; this level is extremely constant.

As shown in figure 2, elevated excretion rates of cyclic GMP were found in children with treated and untreated malignant tumours. The excretion rates of some untreated tumour patients were ten times the normal level as shown in figure 1 . The mean increase in cyclic GMP excretion was lower in patients who were already under radio- or chemotherapy when the first analysis was made (fig. 2). Brain tumours, with 2 exceptions, yielded little or no elevation of the cyclic GMP excretion rate.

Table 1 shows 186 determinations of the excretion rates of cyclic GMP in 70 children older than 2 years bearing malignant tumours or lymphoproliferative diseases. The highest percentage of elevated rates was found in patients with untreated malignant tumours (69 of 87), while in patients with malignant tumours undergoing treatment as well as with malignant tumours in remission the ratio was considerably lower ( 10 of 51 and 17 of 48 , respectively). In a control group of 85 patients with other nonproliferative diseases, 20 also had elevated excretion rates.

Follow-up studies up to 3 years revealed that urinary cyclic GMP excretion drops to near normal values in patients during remission of their disease, while recurrences are accompanied or preceded by a rise of cyclic GMP excretion. In cases of Wilms tumour.(fig. 3) nephrectomy was followed by a drastic drop of cyclic GMP excretion. Another patient (fig. 4) with acute myelosis gave a similar response after chemotherapy. A recurrence of the disease was accompanied by a second increase of cyclic GMP excretion. 


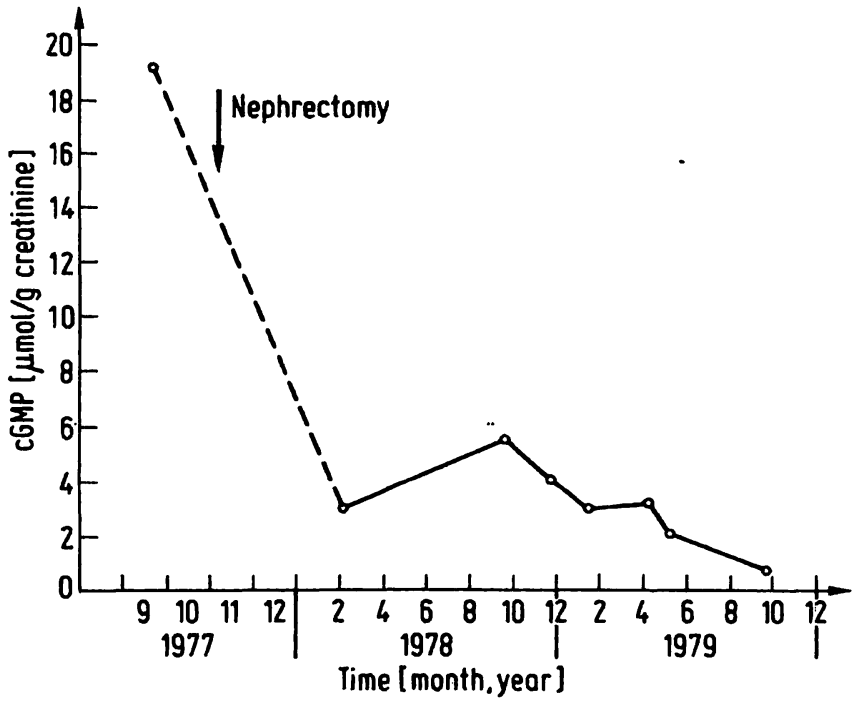

Fig. 3. Follow-up study of urinary cyclic GMP excretion rates: Wilms tumour (stage II) (M.R.) 8. 11. 1977 nephrectomy right, subsequent radiotherapy (18 Gy (1800 rad)) and usual chemotherapy (actinomycin \& vincristine) (11) for 2 years.

Our results for children with malignant tumours should not be generalized to include adults. Adult tumour patients (total 61) also show an increase in $61 \%$ of treated and untreated malignant tumours, but an increase is also found in $38 \%$ of other diseases - especially in cases of myocardial insufficiency (Puschendorf, B., Michelmayr, G. \& Dienstl, F., unpublished results). Only $26 \%$ of patients (total 152 ) with untreated gynaecological tumours showed an increased cyclic GMP excretion in the urine (Puschendorf, $f_{2}$., Santeler, P. \& Dapunt, O., unpublished results).

Together with other clinical parameters the determination of urinary excretion of cyclic GMP seems to be useful for tumour diagnosis and the assessment of therapeutic response in children. So far, the excretion rate of cyclic GMP cannot be correlated with the size or clinical stage of localized tumours, since the number of cases of each type of tumour was too low. However, in 12 patients

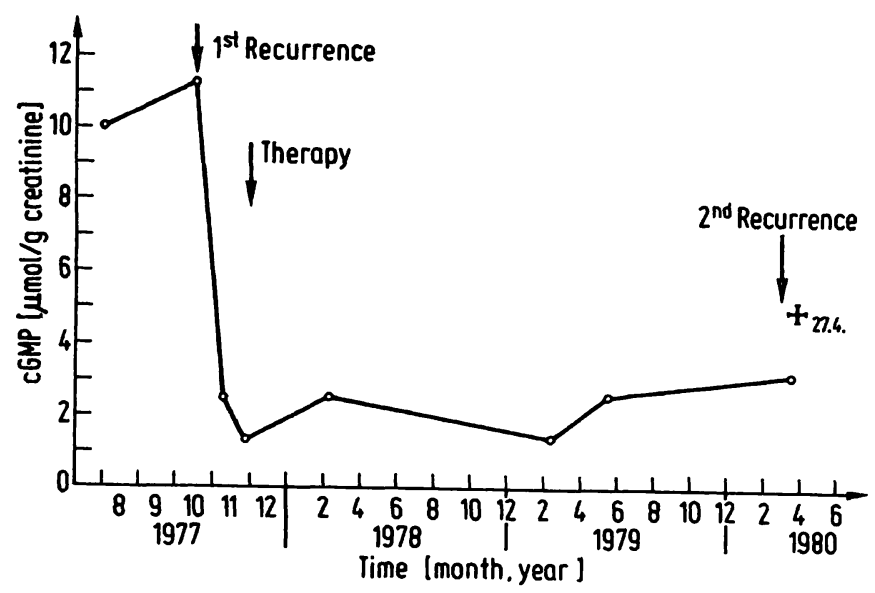

Fig. 4. Follow-up study of urinary cyclic GMP excretion rates: acute lymphatic leukaemia (L.K.), therapy: Ö-76 scheme (vincristine, daunoblastine \& dexamethasone) modified according to Pinkel (12).

with acute lymphatic leukaemia we found that there is no correlation between cyclic GMP and haematological findings.

The determination of cyclic GMP in the urine is of no use for the diagnosis of gynaecological tumours. For other malignant tumours in adults, the measurement of cyclic GMP in urine has approximatively the same value as other in vitro tests available. None of the established in vitro tests gives positive results for all tumour cases. The confidence level of tumour diagnosis by in vitro tests increases with the number of independent tests. In this sense, the determination of cyclic GMP excretion in urine complements the list of in vitro tumour tests.

\section{Acknowledgement}

The authors gratefully acknowledge valuable discussions with Doz. Dr. Elisabeth Wolff-Schreiner and the expert technical assistance of Ms. Dagmar Gruber.

This study was supported by the Vorarlberger Forschungsspende.

\section{References}

1. Hadden, J. W., Hadden, E. M., Haddox, M. K. \& Goldberg, N. D. (1972) Proc. Nat. Acad. Sci. USA 69, 3024-3027.

2. Goldberg, N. D., Haddox, M. K., Estensen, R., White, J. G., Lopez, C. \& Hadden, J. W. (1974) In: The Cold Spring Harbor Symp. on the Regulation of Proliferation in Animal Cells (Clarckson, B. \& Baserga, R. eds.) pp. 609-625, Cold Spring Harbor Laboratory, New York.

3. Murad, F., Kimura, H., Hopkins, H. A., Looney, W. B. \& Kovacs, C. J. (1975) Science 190, 58-60.

4. Criss, W. E. \& Murad, F. (1976) Cancer Res. 36, 1714-1716.

5. Gilman, A. G. (1970) Proc. Nat. Acad. Sci. USA 67, 305312.

6. lliano, G., Tell, G. P. E., Siegel, M. I. \& Cuatrecasas, P. (1973) Proc. Nat. Acad. Sci. USA 70, 2443-2447.
7. Wunderwald, P., Jurz, G. \& Michal, G. (1974) Anal. Biochem. $59,468-481$.

8. Bartels, H., Böhmer, M. \& Heierli, C. (1972) Clin. Chem. Acta 37, 193-197.

9. Rubin, I. M., Bruck, E. \& Rapoport, M. (1949) J. Clin. Invest. $28,1144-1162$.

10. Herrera, C. \& Finer, N. (1976) In: Manual of Pediatric Therapeutics p. 271 (Graef, J. W. \& Cone jr., T. E. eds.) Little, Brown \& Comp., Boston, USA.

11. Plüss, H. J. \& Sartorius, J. A. (1979) In: Internistische Krebstherapie (Brunner, K. W. \& Nagel, G. A., ed.) 2. edition, 454-457, Springer Verlag, Berlin-Heidelberg-New York.

12. Resch, R., Haas, H. \& Berger, H. (1980) Dtsch. Med. Wochenschr. 105, 123-127. 